\title{
Generalised Boyd-Kleinmann coefficients for OPO modelling
}

\author{
Hansen, Peter Lichtenberg; Buchhave, Preben
}

Published in:

Proceedings of the European Quantum Electronics Conference

Publication date:

1998

Document Version

Publisher's PDF, also known as Version of record

Link back to DTU Orbit

Citation (APA):

Hansen, P. L., \& Buchhave, P. (1998). Generalised Boyd-Kleinmann coefficients for OPO modelling. In Proceedings of the European Quantum Electronics Conference (pp. 203-203). IEEE.

\section{General rights}

Copyright and moral rights for the publications made accessible in the public portal are retained by the authors and/or other copyright owners and it is a condition of accessing publications that users recognise and abide by the legal requirements associated with these rights.

- Users may download and print one copy of any publication from the public portal for the purpose of private study or research.

- You may not further distribute the material or use it for any profit-making activity or commercial gain

- You may freely distribute the URL identifying the publication in the public portal

If you believe that this document breaches copyright please contact us providing details, and we will remove access to the work immediately and investigate your claim 
QThG32

Upconversion spectroscopy in rare-earth doped chalcogenide glasses As. Otweirn, M.T. de Aranijo and A.S. Gonvela-Nete Maceió - 57072970 - Al - Brasi.

\author{
A.SB. Sambra and J.A Medeirou Neto
Depertentento de Fisica - Iniversidace Fod \\ Fortaleza - 60455/750 - CE - Foders
}

In recent years, there has been a widespread in the develoment of new host materials to for rarcearth doped solid-state optical devices. Amongt many alternatives, chaleogenide glasses [1] have emerged as serious competitors for applications as in $1.3 \mu \mathrm{m}$ optical fiber amplifiers, mid-infrarod lasers, upeonversion lisers and satturable absorbers [2].

In this work we report, on the infrared-to-visible upconversion fluorescence spectroscopy of

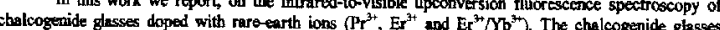
utilized in this work are of types GLS (Gallium-Lenzhanum-Sulphide) and $\mathrm{Ga}_{2} \mathrm{~S}_{3}: \mathrm{L}_{2} \mathrm{O}_{3}$ which is madified version of GLS glass by the addition of tanthanum-oxide, and the samples were pumpod at $1.06 \mu \mathrm{m}$ and $1.54 \mu \mathrm{m}$. For GLS:Pr" pumped at $1.06 \mu \mathrm{m}$, the ressults present the gentration of broad band visible enission in the wavelength region of $590-900 \mathrm{~nm}$. Two-pboton absorption mediated by muthiphonton decays are responsible for the population of excited-states emitting levels. For $\mathrm{Ga}_{2} \mathrm{~S}_{3}: \mathrm{La}_{2} \mathrm{O}_{3}$ samples doped with $\mathrm{Er}_{\mathrm{r}^{3}}$ and $\mathrm{Er}^{3} / \mathrm{Yb}^{3+}$ the results revent the generation of visibic upconversion: emission around $525,550,670,813$ and $925 \mathrm{~mm}$, for 1.06 and 1.54 um pumping wavelengths. As depicted in spectrum of fig. 1. Energy transfer, involving Er-Er and $\mathrm{Er} r \mathrm{Yb}$ ions and multiphonon assisted nonradiative docays account for the excittion mechanism. The dependence of the upconversion processes with excitation intensity, temperature and raro-earth concentrations were also stutied. The high efficiency of the upcoaversion process in these chalcogenide glasses suggest new applications for the material such as upeonversion lasers and upconversion based optical tempertature sensors, and
saturable rbsobers.

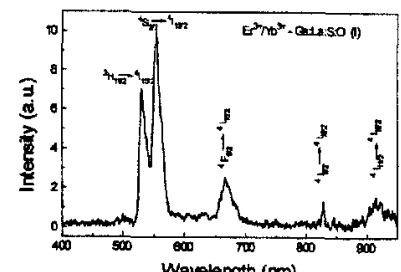

REFERENCES

[1] P.N. Kunta and S.H Risbud, I. Mat. Sci., V. 27, pp. $1135-1158$ (1994)

D.W. Hewak, J.A. Medeiros Neto, B.N. Samson, R.S. Brawn, K.P. Jetrzejewski, J. Wang, E. Taylon,
R.L Laming, G. Wyiangowski and D.N. Payse, IEEE Phot. Techn. Let., V. 6 , pp. $609-612$ (1994)

\section{QThG33}

Generalised Boyd-Kleinmann coefficients for OPO modelling

Peter Lichtenberg Hansen and Preben Buchhave The Optics Group, Department of Physics, Technical University of Denmark DK-2800 Lyngby, Denmark

e-mail: pbu@mips.fvs.du.dk, phone: (45) 45881611 , fax: (45) 45931669

SUMMARY

The fundamental process of the optical parametric oscillator is a parametric coupling of three monochromatic waves. Three wave interaction of focused Gaussian fields was first ronsjdered by Boyd and Kleinmann in the late sixties. In their work the interaction of the three beams was compuled as an overlap integral throughout the crystal resulting in the so-called Boyd-Kleinman reduction factor. Their analysis also takes into account walk-off associaced with an extraordinarily polarised beam propagating in a birefringent crystal. Their description was, however, limited to either ordinary polarised pump and extraordinary polarised signal and idter (oee) or extraordinary polarised punp and ordinary polarised signal and idler ficlds (eoo) usually denoted Type I phase matched interaction. In the following a generalised theory including arbitrary confocal paraineters for the three beams and independent walk-off of any two beam pairs as it occurs in Type II phase matching will be derived.

The derivation of the generalised expressions follows the same procedure as used by Boyd and Kleinmann [1]. However, in the case of Type П phase matching, walk-off leads to expressions that are different from those of Type 1 phase matching. Firstly, walk-off can occur for both the purnp field and the signal or idler fields. and the walk-off angles of the two beams are in general not identical although in the same plane. Secondly, the generalised Boyd-Kleinmann factor becomes wavelength dependent in case of critical Type II phase matching, as the walk-off angle: vary and the beam divergence changes as the system is tuned away from degeneracy.

In our derivation all three bems are assumed to be focused TEM -mode beans with a Caussian In our derivation all three beams are assumed to he focused intensity profile and are allowed to have indepent be beams are ofterc are rather simple one-dimensional integrals.

The derivation of the overlap integrals assumes non-depleted fields. To go further one must etc.). In some of these cases the integrals can be carjed our analytically; in others they must be evaluated numerically. We have used the reduction factors instead in a model, where the crysta is sliced up into small segments normal to the general propagation direction ( $z$-axis) and the changes in the fields computed in each segment. The changed fields are then used as input to the following segment. This way depletion and growth of all three fields can be handled. 